\title{
Reconstruction of recent climate change in Alaska from the Aurora Peak ice core, central Alaska
}

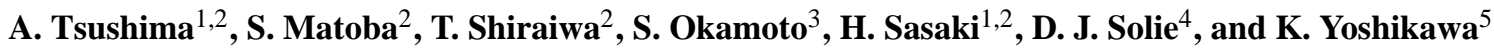 \\ ${ }^{1}$ Graduate School of Environmental Science, Hokkaido University, N10W5, Sapporo 060-0810, Japan \\ ${ }^{2}$ Institute of Low Temperature Science, Hokkaido University, N19W8, Sapporo 060-0819, Japan \\ ${ }^{3}$ Graduate School of Environmental Studies, Nagoya University, Nagoya 464-8601, Japan \\ ${ }^{4}$ Geophysical Institute, University of Alaska Fairbanks, Fairbanks, Alaska, 99775-7320, USA \\ ${ }^{5}$ Water and Environmental Research Center, University of Alaska Fairbanks, Fairbanks, Alaska, 99775-5860, USA \\ Correspondence to: A. Tsushima (a_tsushima@pop.lowtem.hokudai.ac.jp)
}

Received: 10 February 2014 - Published in Clim. Past Discuss.: 8 April 2014

Revised: 10 December 2014 - Accepted: 11 December 2014 - Published: 10 February 2015

\begin{abstract}
A $180.17 \mathrm{~m}$ ice core was drilled at Aurora Peak in the central part of the Alaska Range, Alaska, in 2008 to allow reconstruction of centennial-scale climate change in the northern North Pacific. The $10 \mathrm{~m}$ depth temperature in the borehole was $-2.2^{\circ} \mathrm{C}$, which corresponded to the annual mean air temperature at the drilling site. In this ice core, there were many melt-refreeze layers due to high temperature and/or strong insolation during summer seasons. We analyzed stable hydrogen isotopes $(\delta \mathrm{D})$ and chemical species in the ice core. The ice core age was determined by annual counts of $\delta \mathrm{D}$ and seasonal cycles of $\mathrm{Na}^{+}$, and we used reference horizons of tritium peaks in 1963 and 1964, major volcanic eruptions of Mount Spurr in 1992 and Mount Katmai in 1912, and a large forest fire in 2004 as age controls. Here, we show that the chronology of the Aurora Peak ice core from $95.61 \mathrm{~m}$ to the top corresponds to the period from 1900 to the summer season of 2008, with a dating error of \pm 3 years. We estimated that the mean accumulation rate from 1997 to 2007 (except for 2004) was $2.04 \mathrm{~m} \mathrm{w.eq.yr}^{-1}$. Our results suggest that temporal variations in $\delta \mathrm{D}$ and annual accumulation rates are strongly related to shifts in the Pacific Decadal Oscillation index (PDOI). The remarkable increase in annual precipitation since the 1970s has likely been the result of enhanced storm activity associated with shifts in the PDOI during winter in the Gulf of Alaska.
\end{abstract}

\section{Introduction}

Various atmospheric chemical species transported by atmospheric circulation from oceans, forest fires, deserts, volcanic eruptions, and other sources are deposited with falling snow on glacier surfaces. Ice cores obtained from glaciers and ice sheets are important archives of paleoclimatic change (EPICA Community Members, 2004; Jouzel et al., 2007).

Ice cores can provide extremely valuable data for the analysis of paleoclimate, especially in the northern North Pacific region, which contains limited sources of past meteorological, climatological, and oceanographic data. In the northern North Pacific region, several ice cores have been drilled to study paleoclimate change; e.g., the Mt. Logan, Eclipse Icefield, Mt. Wrangell, and Kahiltna Pass (Holdsworth et al., 1992; Yalcin and Wake, 2001; Moore et al., 2002; GotoAzuma et al., 2003; Shiraiwa et al., 2003; Fisher et al., 2004; Zagorodnov et al., 2005; Kelsey et al., 2010) (Table 1 and Fig. 1). For example, annual accumulation rates and the seasonal variation of $\mathrm{Na}^{+}$concentration have been reported from the Mt. Logan ice core (Holdsworth et al., 1992; Shiraiwa et al., 2003). Additionally, Moore et al. (2002) found the annual snow accumulation of Mt. Logan was associated with both of Pacific North America pattern and the Pacific Decadal Oscillation. The chemical variations have been reported from the Eclipse Icefield snow pit observation and ice core, drilled in 1996 and 2002, respectively (Yalcin and Wake, 2001; Yalcin et al., 2006). In particular, Fisher et al. (2004) mentioned that the moisture source changed with altitude. This was determined by comparison of the 
Table 1. Information from the northern North Pacific ice core records.

\begin{tabular}{|c|c|c|c|c|c|c|c|c|}
\hline Site & $\begin{array}{l}\text { Drilling } \\
\text { year } \\
\text { (AD) }\end{array}$ & Latitude & Longitude & $\begin{array}{l}\text { Elevation } \\
\text { (m a.s.1.) }\end{array}$ & $\begin{array}{l}\text { Mean } \\
\text { temp. } \\
\left({ }^{\circ} \mathrm{C}\right)\end{array}$ & $\begin{array}{l}\text { Accum. rate } \\
\text { (m w.eq. }{ }^{-1} \text { ) }\end{array}$ & $\begin{array}{l}\text { Depth } \\
(\mathrm{m})\end{array}$ & $\begin{array}{l}\text { Time } \\
\text { span } \\
\text { (year) }\end{array}$ \\
\hline \multicolumn{9}{|c|}{ North America } \\
\hline Aurora Peak ${ }^{\mathrm{a}}$ & 2008 & $63.52^{\circ} \mathrm{N}$ & $146.54^{\circ} \mathrm{W}$ & 2825 & -2.2 & $\begin{array}{l}2.04 \text { (1997-2007), } \\
2.13 \text { (2003-2007), } \\
1.87 \text { (1992-2002) }\end{array}$ & 180.17 & 274 \\
\hline $\operatorname{Logan} b, c$ & 1980 & $60.34^{\circ} \mathrm{N}$ & $140.24^{\circ} \mathrm{W}$ & 5340 & - & - & 103 & 301 \\
\hline Eclipse $^{\mathrm{d}}$ & $\begin{array}{l}1996^{\mathrm{e}} \\
2002^{\mathrm{f}}\end{array}$ & $60.51^{\circ} \mathrm{N}$ & $139.47^{\circ} \mathrm{W}$ & 3017 & $\sim-5$ & $\begin{array}{l}1.38^{\mathrm{e}} \\
1.30^{\mathrm{f}}\end{array}$ & $\begin{array}{l}160^{\mathrm{e}} \\
345^{\mathrm{f}}\end{array}$ & $\sim 1000$ \\
\hline $\mathrm{PRCol}^{\mathrm{d}}$ & 2001,2002 & $60.59^{\circ} \mathrm{N}$ & $140.50^{\circ} \mathrm{W}$ & 5340 & -29 & $\sim 0.65$ & 188 & 8000 \\
\hline King $\mathrm{Col}^{\mathrm{d}, \mathrm{g}}$ & 2002 & $60.58^{\circ} \mathrm{N}$ & $140.60^{\circ} \mathrm{W}$ & 4135 & -17 & $\sim 1.00$ & 220.5 & $\sim 300$ \\
\hline Bona-Churchill ${ }^{\mathrm{h}}$ & 2002 & $61.24^{\circ} \mathrm{N}$ & $141.42^{\circ} \mathrm{W}$ & 4200 & -24 & - & 460 & - \\
\hline Wrangell ${ }^{\mathrm{i}}$ & $\begin{array}{l}2003^{\mathrm{j}} \\
2004^{\mathrm{k}}\end{array}$ & $62.00^{\circ} \mathrm{N}$ & $144.00^{\circ} \mathrm{W}$ & 4317 & -18.9 & $\begin{array}{l}2.49(1992-2002)^{\mathrm{j}}, \\
2.66(1992-2004)^{\mathrm{k}}\end{array}$ & $\begin{array}{c}50 \\
212\end{array}$ & 12 \\
\hline Kahiltna Pass ${ }^{1}$ & 2008 & $63.07^{\circ} \mathrm{N}$ & $151.17^{\circ} \mathrm{W}$ & 2970 & - & $2.43(2003-2007)$ & 18.77 & 5 \\
\hline \multicolumn{9}{|c|}{ Kamchatka } \\
\hline Ushkovsky $^{\mathrm{m}}$ & 1998 & $56.04^{\circ} \mathrm{N}$ & $160.28^{\circ} \mathrm{E}$ & 3903 & -15.7 & $0.55^{\mathrm{n}}$ & 211.7 & $640-830^{\circ}$ \\
\hline Ichinsky $\mathrm{p}$ & 2006 & $55.46^{\circ} \mathrm{N}$ & $157.55^{\circ} \mathrm{E}$ & 3607 & -13.0 & $0.68^{\mathrm{q}}$ & 115 & - \\
\hline
\end{tabular}

${ }^{\mathrm{a}}$ This study, ${ }^{\mathrm{b}}$ Holdsworth et al. (1992), ${ }^{\mathrm{c}}$ Moore et al. (2002), ${ }^{\mathrm{d}}$ Fisher et al. (2004), ${ }^{\mathrm{e}}$ Yalcin and Wake (2001), ${ }^{\mathrm{f}}$ Yalcin et al. (2006), ${ }^{\mathrm{g}}$ Goto-Azuma et al. (2003),

${ }^{\mathrm{h}}$ Zagorodnov et al. (2005), ${ }^{\mathrm{i}}$ Shiraiwa et al. (2003), ${ }^{\mathrm{j}}$ Yasunari et al. (2007), ${ }^{\mathrm{k}}$ Kanamori et al. (2008), ${ }^{\mathrm{l}}$ Kelsey et al. (2010), ${ }^{\mathrm{m}}$ Shiraiwa et al. (1999), ${ }^{\mathrm{n}}$ Shiraiwa and Yamaguchi (2002), ${ }^{\circ}$ Shiraiwa et al. (2001), ${ }^{\mathrm{P}}$ Matoba et al. (2007), ${ }^{\mathrm{q}}$ Matoba et al. (2011).

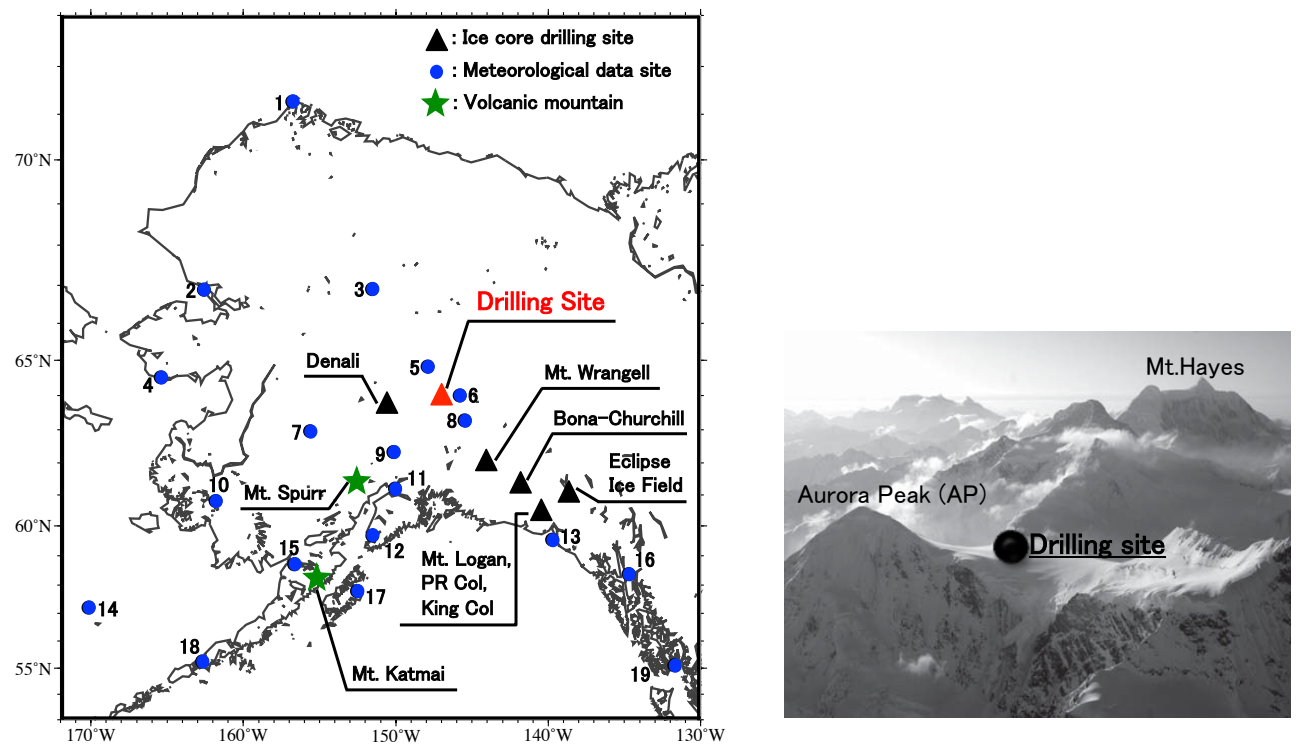

Figure 1. Location of the study area and drilling site at Aurora Peak in the central Alaska Range and meteorological data sites. (Meteorological data sites: 1 Barrow, 2 Kotzebue, 3 Bettels, 4 Nome, 5 Fairbanks, 6 Big Delta, 7 McGrath, 8 Gulkana Glacier, 9 Talkeetna, 10 Bethel, 11 Anchorage, 12 Homer, 13 Yakutat, 14 St Paul, 15 King Salmon, 16 Juneau, 17 Kodiak, 18 Cold Bay, 19 Annette).

stable water isotopes of PR Col (5340 ma.s.1.), King Col (4135 $\mathrm{m}$ a.s.1.), and the Eclipse Icefield (3017 $\mathrm{m}$ a.s.1.).

To reconstruct centennial-scale climatic changes in the northern North Pacific, we studied several ice cores extracted from surrounding regions (Table 1). On the Asian side, in Kamchatka, a $212 \mathrm{~m}$ ice core was drilled at Mount Ushkovsky in 1998 (Shiraiwa et al., 1997, 1999). Shiraiwa and Yamaguchi (2002) showed that reconstructed accumulation rates at Mount Logan and Mount Ushkovsky in Kamchatka were nearly anticorrelated. In 2006, Matoba et 
al. (2007) drilled down to bedrock on a glacier at Mount Ichinsky and recovered a $115 \mathrm{~m}$ ice core. Matoba et al. (2011) determined that negative peaks of stable hydrogen isotopes $(\delta \mathrm{D})$ could be used as an indicator of sea-ice extent in the Sea of Okhotsk. On the North American side, 50 and $212 \mathrm{~m}$ ice cores were drilled at Mount Wrangell in the Wrangell-St Elias Mountains in 2003 and 2004, respectively (Shiraiwa et al., 2004; Kanamori et al., 2008). Yasunari et al. (2007) reported that $\delta \mathrm{D}$ values, tritium concentrations, and dust concentrations showed seasonal variations from 1992 to 2002. Thus, some ice cores on the North American side were drilled in the coastal area of the Gulf of Alaska. To reconstruct climate changes in the northern North Pacific, several additional ice cores from various regions of Alaska and Kamchatka are needed.

During the summer of 2008, we obtained an ice core from the Alaska Range in central Alaska, which preserves a climate record dating back several hundred years. In this paper, we present high-resolution data from this Alaskan ice core for $\delta \mathrm{D}$ and major ion values from the surface to $180.17 \mathrm{~m}$. We also determined the detailed age structure of the ice core. After the ice core had been dated, we estimated annual accumulation rates and evaluated recent climatic changes in Alaska.

\section{Sampling site and methods}

Aurora Peak is located about $15 \mathrm{~km}$ southeast of Mount Hayes. An ice-drilling expedition was carried out at a flat glacier-clad saddle north of Aurora Peak $\left(63.52^{\circ} \mathrm{N}\right.$, $146.54^{\circ} \mathrm{W} ; 2825 \mathrm{~m}$ a.s.l.) in the Alaska Range in 2008. The flat glacier-clad saddle constitutes an ice divide between the Trident Glacier to the north and the Black Rapid/Susitna Glacier to the south (Fig. 1). During the drilling operation, the glacier surface and bed geometry were measured using GPS and ice-penetrating radar (Fukuda et al., 2011). The drilling site was located at the central highpoint of the saddle, with a total ice thickness of $252 \pm 10 \mathrm{~m}$, above a small bedrock dip. Surface flow velocity was measured by surveying poles placed in the glacier surface (Fukuda et al., 2011). The stake motion at $5 \mathrm{~m}$ from the drilling site was $<0.5 \mathrm{~m} \mathrm{yr}^{-1}$, confirming that the advection of ice from the surrounding regions was very small. Thus, the influence of horizontal motion on the ice core was considered to be small.

From May to June 2008, we drilled a $180.17 \mathrm{~m}$ deep ice core. We used an electromechanical ice-core drilling system developed by Geotech Co. Ltd. (Nagoya, Japan). It took $101 \mathrm{~h}$ to drill down to $180.17 \mathrm{~m}$ at a pace of $1.77 \mathrm{~m} \mathrm{~h}^{-1}$. Ice cores $90-93 \mathrm{~mm}$ in diameter and $\sim 0.5 \mathrm{~m}$ long were consistently recovered from each drilling run.

After the drilling had been completed, we examined the stratigraphy of the ice cores using transmitted light and measured the diameter, length, and weight of each ice core segment to calculate its density. The error in density measure- ments was $0.2 \%$. The stratigraphic features showed that the study site should be categorized as a percolation zone. The pore close-off depth was about $55 \mathrm{~m}$. Ice depth was converted into water-equivalent depth using the density profile. The water-equivalent depth at the bottom of the $180.17 \mathrm{~m}$ ice core was $149.68 \mathrm{~m}$. After the drilling operation, we also measured the profile of borehole temperature and constructed a profile. Generally, $10 \mathrm{~m}$ depth temperature corresponds to annual mean air temperature at the drilling site. In Aurora Peak, the $10 \mathrm{~m}$ depth temperature in the borehole was $-2.2{ }^{\circ} \mathrm{C}$. Ice cores were kept frozen and transported from the drilling site to the nearest airport, where they were loaded onto a freezer truck and transported to cold storage in Anchorage. From Anchorage, the samples were kept frozen and transported by a freezer cargo plane and truck to a cold room at the Institute of Low Temperature Science, Hokkaido University.

Ice-core samples were prepared for analysis of stable isotopes and major ions as described below in the cold laboratory $\left(-20^{\circ} \mathrm{C}\right)$ at the Institute of Low Temperature Science, Hokkaido University, Japan. The ice core samples from the surface to $180.17 \mathrm{~m}$ were cut with a saw into quarters along their vertical axes and then cut horizontally into approximately $0.1 \mathrm{~m}$ sections. To avoid possible contamination from drilling and processing, we shaved off the outer surface of each subsample from the surface to $70 \mathrm{~m}$ with a ceramic knife on a clean bench and washed each subsample from below $70 \mathrm{~m}$ with ultrapure water in a stainless steel strainer. The decontaminated samples were packed into polyethylene bags, melted at ambient temperature, and stored in polypropylene bottles. All of the equipment and bottles were pre-cleaned with ultrapure water in an ultrasonic bath.

The stable isotope composition of hydrogen $(\delta \mathrm{D})$ was measured using a mass spectrometer (Isoprime; GV Instruments, UK) with a chromium-reduction system (model Py$\mathrm{rOH}$; Eurovector, Italy). The precision was $\pm 0.1 \%$. The concentrations of major ions $\left(\mathrm{Na}^{+}, \mathrm{NH}_{4}^{+}, \mathrm{K}^{+}, \mathrm{Mg}^{2+}, \mathrm{Ca}^{2+}, \mathrm{Cl}^{-}\right.$, $\mathrm{NO}_{3}^{-}$, and $\mathrm{SO}_{4}^{2-}$ ) were measured using ion chromatography (model DX500; Dionex, USA) with a $0.5 \mathrm{~mL}$ sample loop. For the cation measurements, we used a CS12 column and a $20 \mathrm{mM} \mathrm{CH}_{3} \mathrm{SO}_{3} \mathrm{H}$ eluent. For the anion measurements, an AS14 column and $3.5 \mathrm{mM} / 1.0 \mathrm{mM} \mathrm{Na} 2 \mathrm{CO}_{3} / \mathrm{NaHCO}_{3}$ eluent were used. Determination limits were $10 \mathrm{ppb}$ for all other species. Tritium concentrations were measured using a liquid scintillation counter (model LSC-LB3; Aloka Co. Ltd., Japan). The tritium samples were prepared by mixing $10 \mathrm{~mL}$ subsamples selected after the initial age scale was determined using isotopes and chemistry. The vertical resolution of tritium measurements was $0.5 \mathrm{~m}$. 


\section{Results}

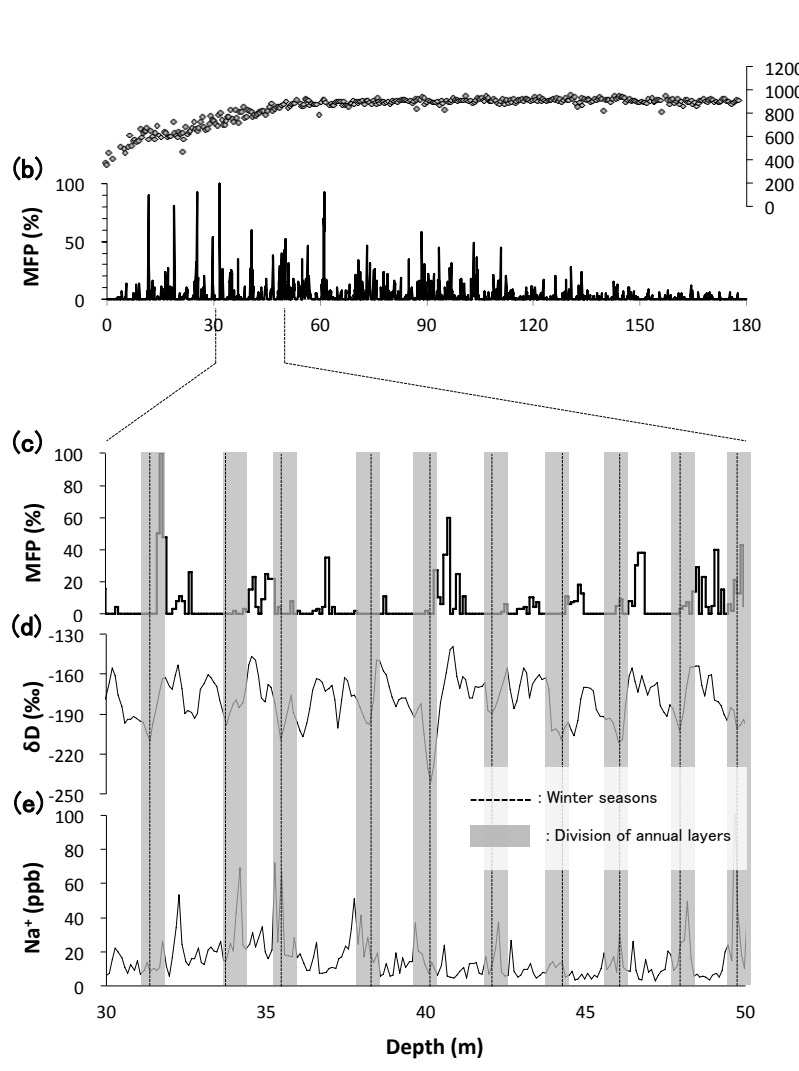

Figure 2 shows profiles of $\delta \mathrm{D}$, melt feature percentage (MFP), and $\mathrm{Na}^{+}$concentration for the ice core. The $\delta \mathrm{D}$ profile exhibits regular cyclic variations. MFP is measured as the thickness of frozen ice layers in a $0.1 \mathrm{~m}$ section of the ice core. MFP is generally used as an indicator of summer temperatures at sites where the ice layers form by melting at the snow surface (Koerner, 1977). We found that the maximum (minimum) values of $\delta \mathrm{D}$ corresponded to the high (low) values of MFP in each cycle. The Aurora Peak ice core was composed mainly of firn partly interbedded with ice layers, as we will discuss later. This indicates that the transformation of snow into ice proceeds in two ways: dry densification and refreezing of meltwater. It is difficult to quantify the contribution of the melting-refreezing process to the densification of firn, because the amount of melting differs from year to year. The melting occurs at the surface of the glacier; the meltwater percolates along a vertical channel and spreads horizontally on favored layers to form an ice layer that can be placed at the previous summer surface, where the size of the snow grains changes abruptly, as mentioned in the previous section. The low temperature of the firn reduces the number of such melting-refreezing processes, however, and the densification with depth proceeds mainly due to dry densification processes in this glacier. Additionally, as shown later, this site has a high accumulation rate. Hence meltwater hardly into the layer of the previous year. As shown in Fig. 2, the density values ratchet up and the ice core closes off at about $55 \mathrm{~m}$. The average annual amplitude of $\delta \mathrm{D}$ recorded in the Aurora Peak ice core from 1735 to 2007 was $30.9 \%$ (Fig. 3). Such high amplitude cannot be maintained if intensive melting occurred in the past. Additionally, at this site, refrozen layers form in the summer snow layer; because the annual accumulation rate is very high, meltwater cannot penetrate the layer from the previous winter (Fig. 4). This suggested limited homogenization due to the melting process. We concluded that the $\delta \mathrm{D}$ profile showed obvious seasonal cycles, in which the high values appeared in summer layers.

The $\mathrm{Na}^{+}$profile also exhibited regular cyclic variations. High concentrations of $\mathrm{Na}^{+}$occurred in winter layers, as determined by the minimum values of $\delta \mathrm{D}$. At the Eclipse Icefield in the Wrangell-St Elias Range, Alaska, sea salt concentrations in the snow pack increase in the autumn-winter season owing to enhanced storm development in the Gulf of Alaska during winter (Yalcin et al., 2006). Our results therefore suggest that minimum $\delta \mathrm{D}$ occurs in winter layers determined by the peaks of $\mathrm{Na}^{+}$.

The age of the ice core was determined by counting annual layers of $\delta \mathrm{D}$ and $\mathrm{Na}^{+}$. Initially, we determined the winter season layer, which has both a negative peak of $\delta \mathrm{D}$ and a positive peak of $\mathrm{Na}^{+}$, temporally. If we could confirm that the MFP peak appeared between the temporal winter layers, we

Figure 2. (a) Ice core density and (b) melt feature percentage (MFP) plotted against the snow depth scale between 0 and $180 \mathrm{~m}$. Then, we show the variation in snow depth scale between 30 and $50 \mathrm{~m}$, (c) the MFP, (d) stable hydrogen isotopes $(\delta \mathrm{D})$, and (e) $\mathrm{Na}^{+}$. Gray shading indicates winter seasons. The dotted lines show the compartmental depths of the annual layers.

would be able to conclusively determine the boundary of the annual layer at the negative peak of $\delta \mathrm{D}$. The age of the first negative peak of $\delta \mathrm{D}$ was the winter season of 2007-2008. The following annual layers were separated by minimum values of $\delta \mathrm{D}$ and maximum values of $\mathrm{Na}^{+}$in the winter layers (Fig. 2). By counting the annual layers, we estimated that the $149.68 \mathrm{~m}$ w.eq. ice core covered the period 1734-2008.

To confirm the dating based on $\delta \mathrm{D}$ and $\mathrm{Na}^{+}$seasonal cycles, we compared the dating of the ice core with reference horizons of known age (Fig. 3). We found a large peak of $\mathrm{NO}_{3}^{-}$and $\mathrm{NH}_{4}^{+}$and a visible dirty layer at $8.55 \mathrm{~m}$ w.eq., which we ascribed to the year 2004. Generally, $\mathrm{NO}_{3}^{-}$ and $\mathrm{NH}_{4}^{+}$are released by forest fires (e.g., Legrand and Mayewski, 1997; Eichler et al., 2011). In 2004, a large fire occurred in central Alaska, with nearly double the area of any previously recorded event $\left(\sim 5261 \mathrm{~km}^{2}\right.$ in total; U.S. National Interagency Fire Center; http://www.nifc. gov/fireInfo/fireInfo_stats_lgFires.html. We calculated nonsea-salt sulfate (nss $\mathrm{SO}_{4}^{2-}$ ) values to differentiate the sulfate signal related to volcanic eruptions from that of seasalt-derived sulfate. The total sulfate concentration was 


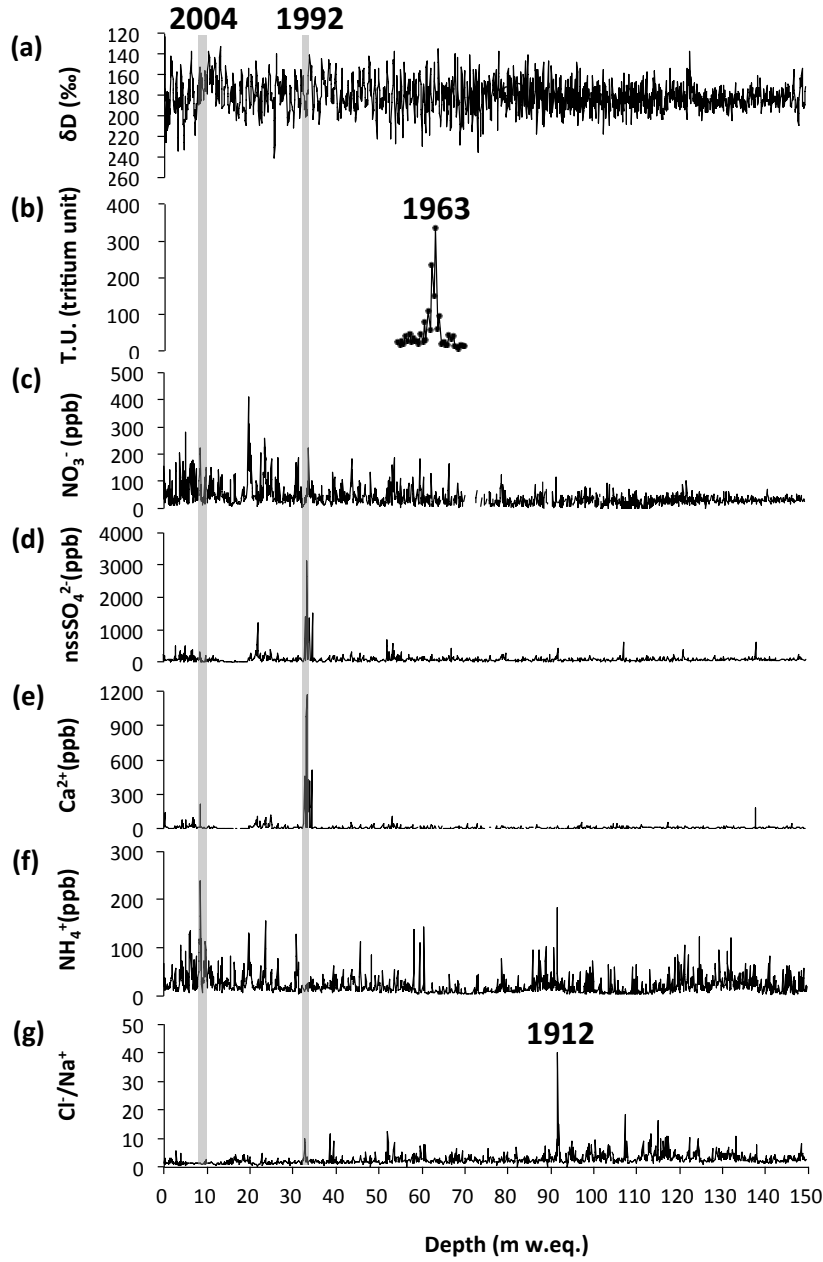

Figure 3. (a) Stable hydrogen isotopes $(\delta \mathrm{D})$, (b) tritium unit, (c) $\mathrm{NO}_{3}^{-}$, (d) non-sea-salt sulfate (nss $\mathrm{SO}_{4}^{2-}$ ), (e) $\mathrm{Ca}^{2+}$, (f) $\mathrm{NH}_{4}^{+}$, and (g) $\mathrm{Cl}^{-} / \mathrm{Na}^{+}$plotted against water equivalent depth. The gray shading indicates dirty layers.

normalized using $\mathrm{Na}^{+}$as a reference species and using the sulfate-to-sodium ratio (0.252) in seawater (Wilson, 1975): $\left(\mathrm{nss} \mathrm{SO}{ }_{4}^{2-}\right)=\left(\mathrm{SO}_{4}^{2-}\right)-0.252\left(\mathrm{Na}^{+}\right)$(Wilson, 1975 ; Legrand and Mayewski, 1997). On average, $94 \%$ of $\mathrm{SO}_{4}^{2-}$ was nss $\mathrm{SO}_{4}^{2-}$. We found a sharp peak in $\mathrm{nss}^{2-} \mathrm{SO}_{4}^{2-}$ and a visible dirty layer at $32.91 \mathrm{~m}$ w.eq., which we ascribed to the year 1992. Generally, $\mathrm{nss} \mathrm{SO}_{4}^{2-}$ is produced secondarily from volcanic $\mathrm{SO}_{2}^{-}$. We interpret the $\mathrm{SO}_{4}^{2-}$ peak at $32.91 \mathrm{~m}$ w.eq. as corresponding to the eruption of Mount Spurr in 1992 (McGimsey et al., 2002). We also found a sharp $\mathrm{Cl}^{-} / \mathrm{Na}^{+}$ peak that we assigned to the year 1912 . $\mathrm{HCl}$ is also produced secondarily from volcanic gas and it increases the $\mathrm{Cl}^{-} / \mathrm{Na}^{+}$ value in the snow pack. We determined that the $\mathrm{Cl}^{-} / \mathrm{Na}^{+}$ peak and visibly dirty layer at $91.63 \mathrm{~m}$ w.eq. were related to the 1912 eruptions of Mount Katmai. We found sharp tritium peaks at 63.3 and $62.4 \mathrm{mw}$ weq. that are reference horizons of H-bomb testing in 1963 and 1964 (Clausen and Hammer,

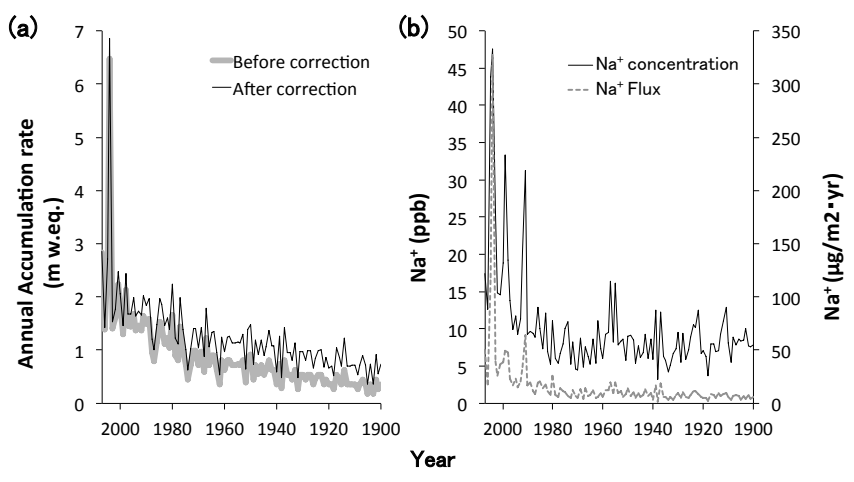

Figure 4. (a) Annual layer thicknesses of the Aurora Peak ice core (thick gray line) and annual accumulation rates corrected by the Dansgaard-Johnsen model (black line). (b) Temporal variations in average annual $\mathrm{Na}^{+}$concentrations (black line) and $\mathrm{Na}^{+}$flux (dotted gray line).

1988). The tritium peak of 1963 and eruption of Mount Katmai in 1912 are provided as reference horizons. The difference between ice core ages estimated by annual counts of $\delta \mathrm{D}$ and tritium was 3 years. In this paper, we discuss the ice core records following 1900 because we could not find an appropriate reference horizon prior to 1912 at Mount Katmai to confirm dating, and there was also uncertainty in the flow model estimate of the vertical strain rate for the bottom part of the ice core.

\subsection{Estimates of annual accumulation rates}

The thicknesses of the annual layers of the ice core were determined from the $\delta \mathrm{D}$ profile, as described above. In a glacier, the thickness of annual layers becomes vertically strained by ice flow. To estimate annual accumulation rates from the ice core, we converted annual layer thickness to annual mass balance using the Dansgaard-Johnsen model (Dansgaard and Johnsen, 1969). We input the total ice thickness $(H)$ of $216 \mathrm{~m}$ w.eq., as measured by icepenetrating radar (Fukuda et al., 2011), the annual accumulation rate of $1.88 \mathrm{~m}$ w.eq. (average value from 1997 to 2007, excluding an exceptional value in 2004), and the critical depth (vertical strain rate constant down to $h$ value) of $0.25 \mathrm{H}$ (Fig. 4). We estimated annual accumulation rates from 1900 to 2007. The annual accumulation rate at Aurora Peak and ice core data from a nearby site are presented in Table 1. The average annual accumulation rate at Aurora Peak from 2003 to 2007 was $2.13 \mathrm{~m}$ w.eq (excluding an exceptional value in 2004), similar to the $2.43 \mathrm{mw}$.eq. $\mathrm{yr}^{-1}$ at Kahiltna Pass (2970 ma.s.l.), Denali National Park, Alaska (Kelsey et al., 2010). However, the average annual accumulation rate at Aurora Peak (1.87w.eq. $\mathrm{yr}^{-1}$, 1992-2002, excluding an exceptional value in 2004) was considerably lower than that $\left(2.49 \mathrm{mw}\right.$.eq. $\mathrm{yr}^{-1}, 1992$ 2002; $2.66 \mathrm{mw}$.eq. $\left.\mathrm{yr}^{-1}, 1992-2004\right)$ at Mount Wrangell 
Table 2. Information on meteorological data sites.

\begin{tabular}{|c|c|c|c|c|c|c|c|c|c|}
\hline \multirow[t]{3}{*}{ No. } & \multirow[t]{3}{*}{ Weather station site } & \multirow[t]{3}{*}{ Latitude } & \multirow[t]{3}{*}{ Longitude } & \multirow{3}{*}{$\begin{array}{l}\text { Elevation } \\
\text { (ma.s.l.) }\end{array}$} & \multirow{3}{*}{$\begin{array}{l}\text { Since } \\
\text { (AD) }\end{array}$} & \multicolumn{4}{|c|}{ No. of data points } \\
\hline & & & & & & \multicolumn{2}{|c|}{ Temperature $\left({ }^{\circ} \mathrm{C}\right)$} & \multicolumn{2}{|c|}{ Precipitation $(\mathrm{mm})$} \\
\hline & & & & & & Annual & 7-year av. & Annual & 7-year av. \\
\hline 1 & Barrow & 71.17 & 156.46 & 9 & 1901 & 94 & 77 & 92 & 76 \\
\hline 2 & Kotzebue & 66.53 & 162.36 & 3 & 1897 & 81 & 65 & 76 & 64 \\
\hline 3 & Bettels & 64.49 & 147.51 & 132 & 1951 & 56 & 51 & 55 & 51 \\
\hline 4 & Nome & 64.31 & 165.27 & 3 & 1900 & 102 & 96 & 101 & 96 \\
\hline 5 & Fairbanks & 64.49 & 147.51 & 132 & 1929 & 78 & 73 & 76 & 72 \\
\hline 6 & Big Delta & 64.00 & 145.43 & 386 & 1937 & 67 & 61 & 67 & 62 \\
\hline 7 & McGrath & 62.57 & 155.36 & 104 & 1941 & 66 & 61 & 65 & 61 \\
\hline 8 & Gulkana Glacier & 63.16 & 145.25 & 1480 & 1968 & 34 & 34 & 37 & 34 \\
\hline 9 & Talkeetna & 62.19 & 150.06 & 105 & 1918 & 89 & 84 & 88 & 84 \\
\hline 10 & Bethel & 60.47 & 161.50 & 38 & 1923 & 81 & 70 & 80 & 70 \\
\hline 11 & Anchorage & 61.11 & 150.00 & 34 & 1952 & 55 & 50 & 54 & 50 \\
\hline 12 & Homer & 59.39 & 151.29 & 27 & 1932 & 75 & 70 & 74 & 70 \\
\hline 13 & Yakutat & 59.31 & 139.38 & 8 & 1917 & 87 & 70 & 86 & 70 \\
\hline 14 & St Paul & 57.10 & 170.13 & 6 & 1892 & 58 & 53 & 57 & 53 \\
\hline 15 & King Salmon & 58.41 & 156.39 & 14 & 1917 & 87 & 67 & 84 & 67 \\
\hline 16 & Juneau & 58.21 & 134.35 & 3 & 1936 & 68 & 62 & 70 & 66 \\
\hline 17 & Kodiak & 57.45 & 152.30 & 4 & 1931 & 76 & 71 & 75 & 71 \\
\hline 18 & Cold Bay & 55.12 & 162.43 & 29 & 1950 & 57 & 52 & 56 & 52 \\
\hline 19 & Annette & 55.03 & 131.34 & 33 & 1941 & 66 & 61 & 65 & 61 \\
\hline
\end{tabular}

(4100 m a.s.l.) in Wrangell-St Elias National Park, Alaska (Yasunari et al., 2007; Kanamori et al., 2008). One obvious reason for Mount Wrangell receiving higher annual precipitation than Aurora Peak is its proximity to the coast.

\section{Discussion}

\subsection{Evaluation of recent climate change in Alaska}

We compared the $\delta \mathrm{D}$ values and annual accumulation rates estimated from the ice core with air temperatures and annual precipitation, respectively, observed at weather stations located in Alaska (Table 2 and Fig. 1; climatological data provided by the Alaska Climate Research Center, http://climate.gi.alaska.edu/index.html, and the U.S. Geological Survey, http://ak.water.usgs.gov/glaciology/gulkana/ index.html). Figure 5 shows the calculated correlation coefficients between the 7-year running averages of $\delta \mathrm{D}$ in the ice core and the air temperatures observed at weather stations in Alaska, and between the annual accumulation rates estimated from the ice core and annual precipitation observed at the weather stations. The $\delta \mathrm{D}$ values and air temperatures were highly correlated in both the central and southern areas (coastal area of the Gulf of Alaska), and the annual accumulation rates and precipitation were also correlated in the southern area. Our results suggest that $\delta \mathrm{D}$ values reflect the air temperatures of both central Alaska and the coastal area of the Gulf of Alaska, and that the annual accumulation rates reflect the precipitation in the coastal area of the Gulf of Alaska. As has been explained above, Fisher et al. (2004) mentioned that the moisture source changed with altitude, and the water vapor at low altitude mainly originated from surrounding ocean area. This was determined by comparison of the stable water isotopes of PR Col (5340 m a.s.l.), King Col (4135 m a.s.1.), and the Eclipse Icefield (3017 m a.s.l.). Aurora Peak is located at a lower altitude (2825 m a.s.l) relative to the Eclipse Icefield (3017 m a.s.1.). We therefore considered the stable water isotopes of Aurora Peak to reflect the local or regional surface climate conditions.

Figure 4 shows that annual accumulation rates estimated from the ice core increased gradually $\left(8 \mathrm{~mm} \mathrm{yr}^{-1}\right.$; excluding an exceptional value in 2004) from 1900 and then increased sharply (23 $\mathrm{mm} \mathrm{yr}^{-1}$; excluding an exceptional value in 2004) around 1976. This trend was also observed in the precipitation data obtained from the 12 weather stations (Barrow, Kotzebue, Bettels, Big Delta, Gulkana Glacier, Anchorage, Homer, Yakutat, King Salmon, Juneau, Kodiak, Cold Bay; Table 3), which corresponded to the ice core record and was observed at both the coastal area of the Gulf of Alaska and a high-latitude area. The difference between the annual accumulation rate at Aurora Peak and the annual precipitation was likely due to differences in altitude.

In the northern North Pacific region, many studies on the relationship between the PDO and climate change have been conducted. In the Alaskan region, it was reported that climate condition (e.g., surface air temperatures and precipitation amounts) and the glacier mass balance reflect the 
Table 3. Increase in the annual accumulation rate of Aurora Peak and annual precipitation amounts observed at weather stations after 1900. Bold numbers indicate sites which had increases of annual accumulation rate and precipitation amounts. Also shown are air temperature records at 15 weather stations during periods I, II, and III, which were correlated with the $\delta$ D of Aurora Peak $(R<0.50, p<0.05)$.

\begin{tabular}{|c|c|c|c|c|c|c|c|c|c|}
\hline \multirow{3}{*}{$\begin{array}{l}\text { Weather station } \\
\text { site }\end{array}$} & \multirow{3}{*}{$\begin{array}{l}\text { Average } \\
\text { (mw.eq.) }\end{array}$} & \multirow{3}{*}{$\begin{array}{r}\text { Increase } \\
\left(\mathrm{mm} \mathrm{yr}^{-1}\right)\end{array}$} & \multirow{3}{*}{$\begin{array}{r}\text { Av. Temp. } \\
\left({ }^{\circ} \mathrm{C}\right)\end{array}$} & \multicolumn{2}{|c|}{$\mathrm{I}^{\mathrm{a}}$} & \multicolumn{2}{|c|}{$\mathrm{II}^{\mathrm{b}}$} & \multicolumn{2}{|c|}{$\mathrm{III}^{\mathrm{c}}$} \\
\hline & & & & \multicolumn{2}{|c|}{$\begin{array}{l}\text { PDOI positive } \\
\text { phase }\end{array}$} & \multicolumn{2}{|c|}{$\begin{array}{l}\text { PDOI negative } \\
\text { phase }\end{array}$} & \multicolumn{2}{|c|}{$\begin{array}{l}\text { PDOI positive } \\
\text { phase }\end{array}$} \\
\hline & & & & $\begin{array}{r}\text { Av. } \\
\text { Temp. } \\
\left({ }^{\circ} \mathrm{C}\right)\end{array}$ & Anomaly & $\begin{array}{r}\text { Av. } \\
\text { Temp. } \\
\left({ }^{\circ} \mathrm{C}\right)\end{array}$ & Anomaly & $\begin{array}{r}\text { Av. } \\
\text { Temp. } \\
\left({ }^{\circ} \mathrm{C}\right)\end{array}$ & Anomaly \\
\hline Aurora Peak & $1.19^{\mathrm{d}}$ & 12.70 & - & - & - & - & - & - & - \\
\hline Barrow & 0.10 & 0.42 & - & - & - & - & - & - & - \\
\hline Kotzebue & 0.21 & 2.21 & - & - & - & - & - & - & - \\
\hline Bettels & 0.36 & 1.29 & -5.30 & - & - & -6.07 & -0.77 & -4.70 & 0.60 \\
\hline Nome & 0.42 & 0.02 & - & - & - & - & - & - & - \\
\hline Fairbanks & 0.28 & 0.08 & -3.25 & -4.81 & -1.56 & -3.60 & -0.36 & -2.19 & 1.05 \\
\hline Big Delta & 0.28 & 0.63 & -1.95 & 1.56 & 3.50 & -2.81 & -0.86 & -1.39 & 0.56 \\
\hline McGrath & 0.44 & -0.12 & -3.26 & -0.94 & 2.32 & -4.01 & -0.75 & -2.64 & 0.63 \\
\hline Gulkana Glacier & 1.00 & 1.07 & -3.83 & - & - & -4.93 & -1.09 & -3.51 & 0.32 \\
\hline Talkeetna & 0.71 & 0.07 & 1.07 & 1.26 & 0.19 & 0.19 & -0.87 & 1.81 & 0.75 \\
\hline Bethel & 0.44 & 0.07 & - & - & - & - & - & - & - \\
\hline Anchorage & 0.40 & 1.07 & 2.41 & - & - & 1.77 & -0.64 & 2.89 & 0.48 \\
\hline Homer & 0.62 & 0.57 & 3.02 & 2.76 & -0.26 & 2.34 & -0.69 & 3.82 & 0.80 \\
\hline Yakutat & 3.49 & 14.09 & 4.28 & 4.87 & 0.59 & 3.54 & -0.75 & 4.63 & 0.35 \\
\hline St Paul & 0.60 & -0.41 & 1.63 & - & - & 1.13 & -0.50 & 2.05 & 0.42 \\
\hline King Salmon & 0.48 & 1.46 & 0.99 & 0.77 & -0.23 & 0.39 & -0.61 & 1.83 & 0.83 \\
\hline Juneau & 1.38 & 8.62 & 5.04 & 6.56 & 1.52 & 4.32 & -0.72 & 5.59 & 0.55 \\
\hline Kodiak & 1.69 & 9.49 & 5.00 & 5.47 & 0.48 & 4.55 & -0.45 & 5.28 & 0.28 \\
\hline Cold Bay & 0.97 & 7.74 & 3.55 & - & - & 3.17 & -0.38 & 3.86 & 0.31 \\
\hline Annette & 2.71 & -2.94 & 7.77 & 8.53 & 0.76 & 7.41 & -0.36 & 8.10 & 0.32 \\
\hline
\end{tabular}

a $1923-1942,{ }^{\text {b }} 1943-1975,{ }^{\mathrm{c}} 1976-2007,{ }^{\mathrm{d}}$ excluding an exceptional value in 2004.

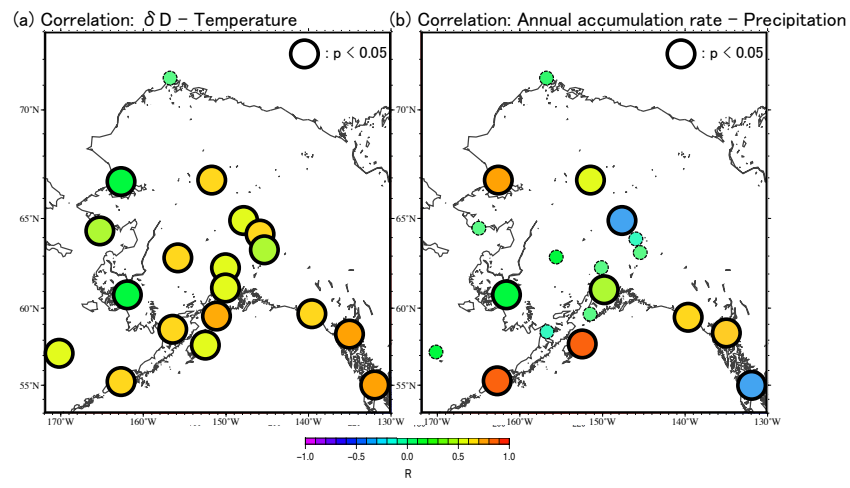

Figure 5. (a) Correlations between 7-year running-average stable hydrogen isotope $(\delta \mathrm{D})$ values of the Aurora Peak ice core and 7-year running-average temperatures at the weather stations. (b) Correlations between 7-year running-average annual accumulation rates estimated for the Aurora Peak ice core and 7-year running-average precipitation data at the weather stations. The thick black circles indicate sites that were statistically significant at the $95 \%$ level.
PDO (Walter and Meier, 1989; McCabe and Fountain, 1995; Mantua et al., 1997; Papineau, 2001; Rodionov at al., 2007; Bienek at al., 2014). The Pacific Decadal Oscillation index (PDOI) was introduced by Mantua et al. (1997) and is based on an empirical orthogonal function (EOF) analysis of sea-surface temperature (SST) in the North Pacific, north of $20^{\circ} \mathrm{N}$. In an analysis of an ice core from Mount Logan (5343 m a.s.l.), Moore et al. (2002) found that annual accumulation increased slightly from 1850 to 2000 , and sharply from 1976. They suggested that the sharp increase in annual accumulation after 1976 was associated with a shift in the Pacific Decadal Oscillation index (PDOI). Our results suggest that the stable hydrogen isotope and annual accumulations of the Aurora Peak ice core reflect the surface air temperatures and precipitation amounts in Alaska, respectively. We consider that the stable hydrogen isotope and annual accumulations of the Aurora Peak ice core also might have a relationship with PDO. This is why we compared the Aurora Peak ice core record with the PDOI. Figure 6 shows the temporal variation in annual average $\delta \mathrm{D}$ values, annual accumulation rates, detrended annual accumulation rates, and the 


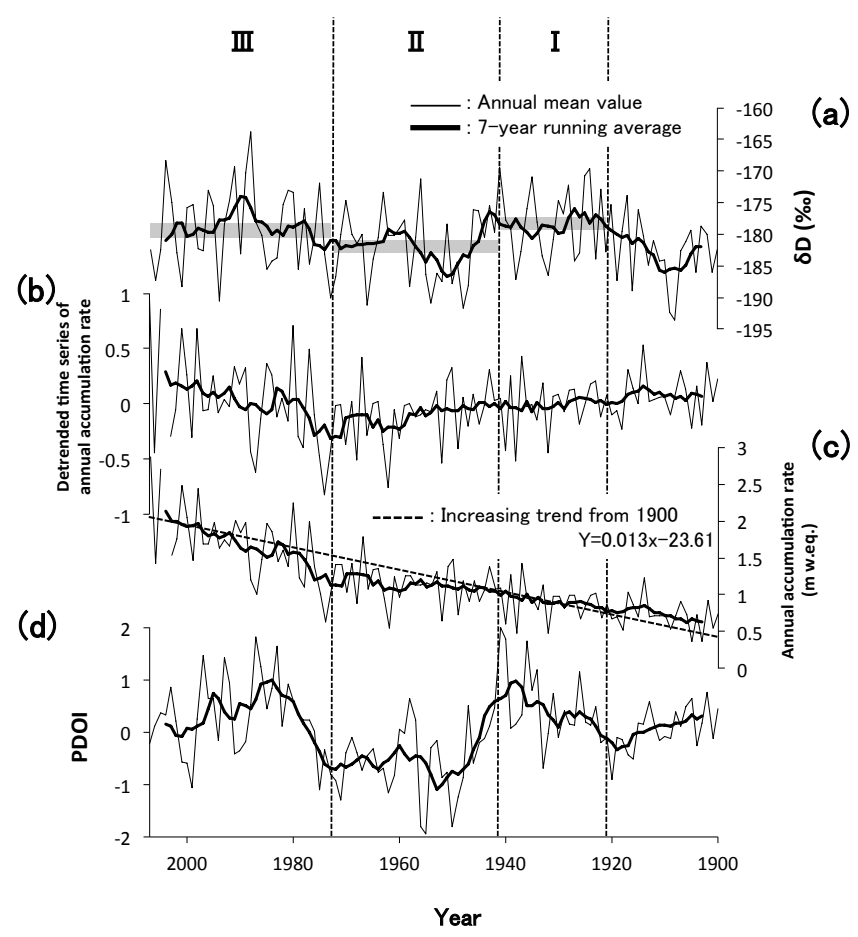

Figure 6. (a) Temporal variation in stable hydrogen isotopes $(\delta \mathrm{D})$. The thick gray lines indicate average values of $\delta \mathrm{D}$ in periods I (1923-1942), II (1943-1975), and III (1976-2007). (b) Detrended annual accumulation rates, which exclude the increasing trend from the annual accumulation rates. (c) Annual accumulation rates of the Aurora Peak ice core. Dotted lines show the increasing trend from 1900. (d) The Pacific Decadal Oscillation index (PDO). Annual mean value given by the gray line; 7-year running averages given by the thick black line.

PDOI from 1900 to 2007 (http://jisao.washington.edu/pdo/ PDO.latest; Mantua et al., 1997; Zhang et al., 1997). The variation in $\delta \mathrm{D}$ values corresponded to PDOI values. This correlation was more obvious in the 7-year running averages; the correlation was 0.57 , which was statistically significant at the $95 \%$ level. The PDOI shifted in 1923, 1943, and 1976 , and the average values of $\delta \mathrm{D}$ in periods I (1923-1942), II (1943-1975), and III (1976-2007) were - 178.3, -181.9, and $-178.8 \%$, respectively. Differences observed among the average values of $\delta \mathrm{D}$ during these three periods were significant at the $95 \%$ level. Thus, periods (I, II, III) when the PDOI increased (decreased) corresponded to the periods when $\delta \mathrm{D}$ increased (decreased). Papineau (2001) reported that temperature and the PDOI were correlated in central Alaska, especially in winter. Table 3 presents the variation in air temperature recorded at 15 weather stations during periods I, II, and III, which were correlated with $\delta \mathrm{D}(R<0.50$, $p<0.05)$. The average temperature anomalies for periods I, II, and III were $+0.73^{\circ} \mathrm{C},-0.65^{\circ} \mathrm{C}$, and $+0.55^{\circ} \mathrm{C}$, respectively.
In contrast, the annual accumulation rates did not show a relationship with PDOI, likely due to the sharp increase in rates that was observed in the later part of the century. We excluded the effect of the long-term increasing trend from 1900 to clarify the short-term trend. For the period 1900-2007, the correlation between detrended annual accumulation rates and the PDOI was 0.45 , which was statistically significant at the $95 \%$ level. Therefore, our results suggest that the annual accumulation rate is associated with the PDOI.

During Positive PDOI periods the Aleutian low develops in the south of Alaska. This increases the precipitation amount and temperature by enhancement of the southerly wind in Alaska (Minobe, 1997; Minobe and Nakanowatari, 2002; Nakanowatari and Minobe, 2005). As shown in Fig. 5, $\delta \mathrm{D}$ and detrended annual accumulation rates have a high correlation with air temperature and precipitation amount in Alaska, respectively. We therefore consider the Aurora Peak ice core record to be a good indicator of the PDOI. Because the reconstructed annual accumulation rates have high correlation with the precipitation amount only in coastal areas, we suppose that precipitation might have been blocked by the high mountain range. Moisture from the south just barely penetrates into central Alaska (e.g., Fairbanks, Big Delta). Aurora Peak is located at a higher altitude than the weather stations so the annual accumulation rate estimated from Aurora Peak might have reflected the precipitation in the coastal area.

Both $\mathrm{Na}^{+}$concentrations and $\mathrm{Na}^{+}$flux in the ice core increased from the 1970 s, along with the annual accumulation rate, although the increase in $\mathrm{Na}^{+}$concentrations was slow from the beginning of the 1900s (Fig. 4). The average increases in $\mathrm{Na}^{+}$from 1976 to 2007 and 1900 to 1975 were 0.71 and $-0.0052 \mathrm{ppbyr}^{-1}$, respectively. $\mathrm{Na}^{+}$in North Pacific ice cores originates from sea salt, and precipitation caused by strong storm activity contains high concentrations of sea salt. As discussed previously, the Aurora Peak ice core also records winter precipitation that contains high concentrations of sea salt, which were likely caused by enhanced development of traveling cyclones. Suzuki (1983) and Suzuki and Endo (1995) observed winter precipitation in Japan and reported that the concentration of sea salt in precipitation was controlled by the position and strength of storms. Our results suggest that the increased $\mathrm{Na}^{+}$concentrations after the 1970 s resulted from changes in the position and/or strength of winter storms in the Gulf of Alaska. We also suggest that the increased annual accumulation at Aurora Peak from 1976 was a result of changes in storm position and/or strength, which might have been associated with the PDOI shift in 1976.

\section{Conclusions}

A $180.17 \mathrm{~m}$ ice core from Aurora Peak in the Alaska Range was analyzed for $\delta \mathrm{D}$ and chemical species. We estimated the age of the ice core by counting annual cycles of $\delta \mathrm{D}$ and $\mathrm{Na}^{+}$. 
We used tritium-peak reference horizons of 1963 and 1964, major volcanic eruptions of Mount Spurr in 1992 and Mount Katmai in 1912, and a large-scale forest fire in 2004 as age controls. Here, we showed that the chronology of the Aurora Peak ice core from $95.61 \mathrm{~m}$ to the top corresponds to the period from 1900 to the summer season of 2008. After dating, we estimated annual accumulation rates using annual layer thicknesses from the ice core, which was corrected using the Dansgaard and Johnsen (1969) approach. The $\delta \mathrm{D}$ values reflected the temperatures of both central Alaska and the coastal area of the Gulf of Alaska, and the annual accumulation rate reflected the annual precipitation in the coastal area of the Gulf of Alaska. The $\delta \mathrm{D}$ values were highly correlated with the PDOI. Close relationships are observed between PDOI, temperature, and $\delta \mathrm{D}$ mean levels. Annual accumulation rates increased gradually from 1900 onwards, which corresponded to increases in annual precipitation recorded at weather stations in Alaska. From 1976 onwards, annual accumulation rates rose sharply; around the same time, concentrations of sea salt began to increase as well. We attribute this phenomenon to enhanced winter storm development in the Gulf of Alaska as a result of the 1976 shift in the PDOI. Consequently, the $\delta \mathrm{D}$ values and annual accumulation rates calculated from the Aurora Peak ice core can be used as indicators of air temperature and annual precipitation, respectively, in the coastal area of the Gulf of Alaska. Recent climatic change in the coastal area of the Gulf of Alaska was closely related to shifts in the PDOI.

Acknowledgements. We thank S. Sugiyama and T. Fukuda for their help in the field research. We also thank C. S. Benson for his kind support, and M. Watanabe for ion chromatography measurements. P. Claus of Ultima Thule Outfitters supported our flight operation with his excellent aircraft. We are very grateful to the editor and three referees for valuable comments and suggestions. This work is a contribution to the Amur-Okhotsk Project, promoted by the Research Institute of Humanity and Nature. This research was supported by JSPS KAKENHI grant nos. 19340137 and 26400460.

Edited by: V. Masson-Delmotte

\section{References}

Bienek, A. P., Walsh, E. J., Thoman, L. R., and Bhatt, S. U.: Using climate divisions to analyze variations and trends in Alaska temperature and precipitation, J. Climate, 27, 2800-2818, doi:10.1175/JCLI-D-13-00342.1, 2014.

Clausen, H. B. and Hammer, C. U.: The Laki and Tambora eruptions as revealed in Greenland ice cores from 11 locations, Ann. Glaciol., 10, 16-22, 1988.

Dansgaard, W. and Johnson, S. J.: A flow model and time scale for the ice core from Camp Century, Greenland, J. Glaciol., 8, 215223, 1969.

Eichler, A., Tinner, W., Brütsch, S., Olivier, S., Papina, T., and Schwikowski, M.: An ice-core based history of Siberian for- est fires since AD 1250, Quaternary Sci. Rev., 30, 1027-1034, doi:10.1016/j.quascirev.2011.02.007, 2011.

EPICA Community Members: Eight glacial cycles from an Antarctic ice core, Nature, 429, 623-628, doi:10.1038/nature02599, 2004.

Fisher, D. A., Wake, C., Kreutz, K., Yalcin, K., Steig, E., Mayewski, P., Anderson, L., Zheng, J., Rupper, S., Zdanowicz, C., Demuth, M., Waszkiewicz, M., Dahl-Jensen, D., Goto-Azuma, K., Bourgeois, J. B., Koerner, R. M., Sekerka, J., Osterberg, E., Abbott, M. B., Finney, B. P., and Burns, S. J.: Stable isotope records from Mount Logan, Eclipse ice cores and nearby Jellybean Lake. Water cycle of the North Pacific over 2000 years and over five vertical kilometers: sudden shifts and tropical connections, Geogr. Phys. Quatern., 58, 337-352, 2004.

Fukuda, T., Sugiyama, S., Matoba, S., and Shiraiwa, T.: Glacier flow measurement and radio-echo sounding at Aurora Peak, Alaska, in 2008, Ann. Glaciol., 52, 138-142, 2011.

Goto-Azuma, K., Shiraiwa, T., Matoba, S., Segawa, T., Kanamori, S., Fujii, Y., and Yamasaki, T.: An overview of the Japanese glaciological studies on Mt. Logan, Yukon Territory, Canada in 2002, Bulletin of Glaciological Research, 20, 65-72, 2003.

Holdsworth, G., Krouse, H. R., and Nosal, M.: Ice core climate signals from Mount Logan, Yukon, AD 1700-1987, in: Climate since AD 1500, edited by: Bradley, R. S. and Jones, P. D., London, Routledge, 483-504, 1992.

Jouzel, J., Masson-Delmotte, V., Cattani, O., Dreyfus, G., Falourd, S., Hoffmann, G., Minster, B., Nouet, J., Barnola, J. M., Chappellaz, J., Fischer, H., Gallet, J. C., Johnsen, S., Leuenberger, M., Loulergue, L., Luethi, D., Oerter, H., Parrenin, F., Raisbeck, G., Raynaud, D., Schilt, A., Schwander, J., Selmo, E., Souchez, R., Spahni, R., Stauffer, B., Steffensen, J. P., Stenni, B., Stocker, T. F., Tison, J. L., Werner, M., and Wolff, E. W.: Orbital and Millennial Antarctic Climate Variability over the Past 800,000 Years, Science, 317, 793-797, doi:10.1126/science.1141038, 2007.

Kanamori, S., Benson, C. S., Truffer, M., Matoba, S., Solie, D. J., and Shiraiwa, T.: Seasonality of snow accumulation at Mount Wrangell, Alaska, USA, J. Glaciol., 54, 273-278, 2008.

Kelsey, E. P., Wake, C. P., Kreutz, K., and Osterberg, E.: Ice layers as an indicator of summer warmth and atmospheric blocking in Alaska, J. Glaciol., 56, 715-722, 2010.

Koerner, C. R. M.: Devon Island ice cap: core stratigraphy and paleoclimate, Science, 196, 15-18, doi:10.1126/science.196.4285.15, 1977.

Legrand, M. and Mayewski, P.: Glaciochemistry of polar ice cores: a review, Rev. Geophys., 35, 219-243, doi:10.1029/96RG03527, 1997.

Mantua, N. J., Hare, S. R., Zhang, Y., Wallace, J. M., and Francis, R. C.: A Pacific interdecadal climate oscillation with impacts on salmon production, B. Am. Meteorol. Soc., 78, 1069-1079, 1997.

Matoba, S., Ushakov, S. V., Shimbori, K., Sasaki, H., Yamasaki, T., Ovshannikov, A. A., Manevich, A. G., Zhideleeva, T. M., Kutuzov, S., Muravyev, Y. D., and Shiraiwa, T.: The glaciological expedition to Mount Ichinsky, Kamchatka, Russia, Bulletin of Glaciological Research, 24, 79-85, 2007.

Matoba, S., Shiraiwa, T., Tsushima, A., Sasaki, H., and Muravyev, Y. D.: Records of sea-ice extent and air temperature at the Sea of Okhotsk from an ice core of Mount Ichinsky, Kamchatka, Ann. Glaciol., 52, 44-50, 2011. 
McCabe, G. J. and Fountain, A.: Relations between atmospheric circulation and mass balance of South Cascade Glacier, Arct. Antarct. Alp. Res., 27, 226-233, 1995.

McGimsey, R. G., Neal, C. A., and Riley, C. M.: Areal Distribution, Thickness, Mass, Volume, and Grain Size of TephraFall Deposits from the 1992 Eruptions of Crater Peak Vent, Mt. Spurr Volcano, Alaska, U.S. Geol. Surv. Open File Report, 01370, 38 pp., available at: http://geopubs.wr.usgs.gov/open-file/ of01-370/, last access: April 2014, 2002.

Minobe, S.: A 50-70 year climatic oscillation over the North Pacific and North America, Geophys. Res. Lett., 24, 683-686, 1997.

Minobe, S. and Nakanowatari, T.: Global structure of bidecadal precipitation variability in boreal winter, Geophys. Res. Lett., 29, 35-1-35-4, doi:10.1029/2001GL014447, 2002.

Moore, G. W. K., Holdsworth, G., and Alverson, K.: Climate change in the North Pacific region over the past three centuries, Nature, 420, 401—403, doi:10.1038/nature01229, 2002.

Nakanowatari, T. and Minobe, S.: Moisture balance for bidecadal variability of wintertime precipitation in the North Pacific Using NCEP/NCAR reanalysis, J. Meteorol. Soc. Jpn., 83, 453-469, 2005.

Papineau, J. M.: Wintertime temperature anomalies in Alaska correlated with ENSO and PDO, Int. J. Climatol., 21, 1577-1592, doi:10.1002/joc.686, 2001.

Rodionov, S. N., Bond, N. A., and Overland, J. E.: The Aleutian Low, storm tracks, and winter climate variability in the Bering Sea, Deep-Sea Res. Pt. II, 54, 2560-2577, doi:10.1016/j.dsr2. 2007.08.002, 2007.

Shiraiwa, T. and Yamaguchi, S.: Reconstruction of glacier mass balances and climate changes in the Kamchatka Peninsula, Tokyo Geographical Society, Journal of Geography, 111, 476-485, 2002 (in Japanese with English abstract and figure captions).

Shiraiwa, T., Muravyev, Y. D., and Yamaguchi, S.: Stratigraphic features of firn as proxy climate signals at the summit ice cap of Ushkovsky volcano, Kamchatka, Russia, Arct. Antarct. Alp. Res., 29, 414-421, doi:10.2307/1551989, 1997.

Shiraiwa, T., Nishio, F., Kameda, T., Takahashi, A., Toyama, Y., Muravyev, Y. D., and Obsyannikov, A.: Ice core drilling at Ushkovsky ice cap, Kamchatka, Russia, Japanese Society of Snow and Ice, Seppyo, 61, 25-40, doi:10.5331/seppyo.61.25, 1999 (in Japanese with English abstract and figure captions).
Shiraiwa, T., Murav’yev, Y. D., Kameda, T., Nishio, F., Toyama, Y., Takahashi, A., Ovsyannikov, A. A., Salamatin, A. N., and Yamagata K.: Characteristics of a crater glacier at Ushkovsky volcano, Kamchatka, Russia, as revealed by the physical properties of ice cores and borehole thermometry, J. Glaciol., 47, 423-432, doi:10.3189/172756501781832061, 2001.

Shiraiwa, T., Goto-Azuma, K., Matoba, S., Yamasaki, T., Segawa, T., Kanamori, S., Matsuoka, K., and Fujii, Y.: Ice core drilling at King Col, Mount Logan 2002, Bulletin of Glaciological Research, 20, 57-63, 2003.

Shiraiwa, T., Kanamori, S., Benson, C. S., Solie, D., and Muravyev, Y. D.: Shallow ice-core drilling at Mount Wrangell, Alaska, Bulletin of Glaciological Research, 21, 71-77, 2004.

Suzuki, K.: A chemical study of snow in Sapporo, Geographical review of Japan, 56, 171-184, 1983 (In Japanese with English abstract and figure captions).

Suzuki, K. and Endo, Y.: Relation of $\mathrm{Na}^{+}$concentration and $\delta^{18} \mathrm{O}$ in winter precipitation with weather conditions, Geophys. Res. Lett., 22, 591-594, doi:10.1029/95GL00160, 1995.

Walters, R. A. and Meier, M. F.: Variability of glaciers mass balances in western North America, in: Aspects of Climate Variability in the Pacific and Western Americas, edited by: Peterson, D. H., American Geophysical Union, Geoph. Monog. Series, Amer. Geophys. Union, 55, 365-374, 1989.

Wilson, T. R. S.: Salinity and the major elements of sea water, in: Chemical Oceanography, edited by: Riley, J. P. and Skittow, G., Academic Press, London, 1, 365-413, 1975.

Yalcin, K. and Wake, C. P.: Anthropogenic signals recorded in an ice core from Eclipse Icefield, Yukon Territory, Canada, Geophys. Res. Lett., 28, 4487-4490, 2001.

Yalcin, K., Wake, C. P., Kang, S., Kreutz, K. J., and Whitlow, S. I.: Seasonal and spatial variability in snow chemistry at Eclipse Icefield, Yukon Territory, Canada, Ann. Glaciol., 43, 230-238, 2006.

Yasunari, T. J., Shiraiwa, T., Kanamori, S., Fujii, Y., Igarashi, M., Yamazaki, K., Benson, C. S., and Hondoh, T.: Intra-annual variations in atmospheric dust and tritium in the North Pacific region detected from an ice core from Mount Wrangell, Alaska, J. Geophys. Res., 112, doi:10.1029/2006JD008121, 2007.

Zagorodnov, V., Thompson, L. G., Ginot, P., and Mikhalenko, V.: Intermediate-depth ice coring of high-altitude and polar glaciers with a lightweight drilling system, J. Glaciol., 51, 491-501, 2005.

Zhang, Y., Wallace, J. M., and Battisti, D. S.: ENSO-like interdecadal variability, J. Climate, 10, 1004-1020, 1997. 